\title{
LEARNING ORGANIZATION IN DETERMINING SUPPLY CHAIN PERFORMANCE
}

\author{
Khairul Ikhwan*)1, Budi Rahardjo*), Shinta Ratnawati*) \\ ${ }^{*}$ Department of Management, Faculty of Economics, Tidar University \\ Jl. Captain Suparman 39 Potrobangsan, North Magelang, Central Java 56116, Indonesia
}

\begin{abstract}
Most learning organization studies have focused on enhancing the organization's performance. However, learning organization extends beyond knowledge management that makes the organization more adaptable and more responsive to the challenges of a fast-changing business environment. The application of a learning organization is an alternative step for companies to be able to face the challenges of the fast-changing business environment. This paper aims to identify the effect of learning organizations on supply chain performance. This study adds the effect of transformational leadership as a variable that affects the comprehensive understanding of learning organizations to gain a. Structural Equation Modelling - Partial Least Square (SEM-PLS) was used to reveal that learning organization has no significant impact on supply chain performance. However, learning organization affected supply chain driver. The Supply chain driver has a positive and significant impact on supply chain performance. Leadership style has a positive and significant impact on learning organization. Organization can make better decisions on choosing facilities more efficiently, managing supplies efficiently and be can use the information itself to increase profits by implementing learning organization.
\end{abstract}

Keywords: learning organization, SEM-PLS, supply chain performance, leadership, supply chain driver

\begin{abstract}
Abstrak: Kebanyakan penelitian organisasi pembelajar berfokus pada peningkatan kinerja organisasi. Bagaimanapun, bahasan mengenai organisasi pembelajar meluas pada bahasan mengenai manajemen pengetahuan yang membuat organisasi lebih mudah beradaptasi dan responsif terhadap tantangan lingkungan bisnis yang berubah semakin cepat. Penerapan organisasi pembelajaran adalah langkah alternatif bagi perusahaan untuk dapat menghadapi tantangan dari lingkungan bisnis yang semakin cepat berubah. Makalah ini bertujuan untuk mengidentifikasi pengaruh organisasi pembelajaran terhadap kinerja rantai pasok. Penelitian ini menambahkan pengaruh kepemimpinan transformasional sebagai variabel yang mempengaruhi pemahaman komprehensif organisasi pembelajar. Structural Equation Model Partial Least Square (SEM-PLS) digunakan dalam membuktikan bahwa organisai pembelajar tidak memiliki pengaruh signifikan terhadap kinerja rantai pasok. Namun demikian, organisasi pembelajar mempengaruhi penggerak rantai pasok. Penggerak rantai pasok memiliki dampak positif dan signifikan terhadap kinerja rantai pasok. Gaya kepemimpinan memiliki dampak positif dan signifikan pada organisasi pembelajar. Organisasi dapat membuat kebutusan yang lebih baik dalam memilih fasilitas yang lebih efisien, mengatur pasokan dengan efisien dan dapat menggunakan informasi yang mereka miliki untuk meningkatkan keuntungan dengan mengimplementasi organisasi pembelajar.
\end{abstract}

Kata kunci: organisasi pembelajar, SEM-PLS, kinerja rantai pasok, kepemimpinan, penggerak rantai pasok

${ }^{1}$ Corresponding author:

Email: khairulikhwan@untidar.ac.id 


\section{INTRODUCTION}

Facing a disruptive era requires businesses to be more efficient and creative in running their businesses. In this era, businesses must respond faster to the challenges and change in the accelerated business environments. An adaptive business is determined by the organizational model it owns, so it must be carefully considered to determine the organizational model of the business. The organizations must also be sensitive enough to adapt to change (Wen, 2014). The organizations' efforts in managing knowledge and developing their structural capital have resulted in relatively excellence business performance. The adoption of intellectual capital can solve the accelerating challenges and changing business environments (Santos et al. 2012).

A good organization can effectively deal with four major challenges: the complexity of the situation, changes in the environment, interactions and sustainable development (Wen, 2014). Through good knowledge management, organizations can acquire strong knowledge to meet these challenges. Knowledge is called a key intangible resource and valuable organizational assets, which is the basis for competitive advantage and sustainable development (Allameh \& Zare, 2011). In addition, providing knowledge can strengthen human resources (Akhmadi et al. 2016).

A good organization can understand the complexity of the environment through collective intelligence. Organizations must have the ability to think about a larger system. Organizations must learn to create organizations, act and innovate (Wen, 2014). Through knowledge management, learning capacity can be improved. Knowledge management converts data, information, and intellectual assets into value. Knowledge management identifies knowledge to improve the availability and accessibility of knowledge at the right time for the right person. Knowledge impro the products, the process, and the value of people (Nold, 2011). The basic practices of learning organizations are an effort to rely on dream, commitment, interpersonal skills, care, trust and collective intelligence (Wen, 2014).

Learning organizations are defined as collective capabilities based on experience and cognitive processes. The collective ability of learning organizations involves knowledge acquisition, knowledge sharing, and utilization of knowledge (Baba, 2015). Organizational learning is a key mechanism for adapting to changes in the organizational environment, sharing knowledge and experience, and providing innovative solutions (Styhre et al. 2010).

Learning organizations in many studies show very important roles in different forms of organizational performance (Hung et al. 2010; Hussein et al, 2014; Kim et al. 2017). The advantages of applying learning organization are enormous. Most studies in the field of learning organizations have only focused on its effects toward organizational performance (Aragón et al. 2014; Hussein et al. 2014). However, the impact of learning organization on supply chain performance remains unclear.

Study conducted by (Ikhwan, Sukmawati, \& Cahyadi, 2018) using situational leadership on determining learning organization (Ikhwan, Sukmawati, \& Cahyadi, 2018). This study, then, adds the transformational leadership style that determining learning organization. The transformational leadership is contextually different from situational leadership. Situational leadership theory proposes that effective leadership requires a rational understanding of the situation and appropriate responses (Grint, 2014). The situational leadership theory represents the degree to which leaders focus on required tasks or focus on their relationships with their followers (McCleskey, 2014). In the transformational leadership, leaders achieve results by employing idealized influence, inspirational motivation, intellectual stimulation, and individualized consideration. The addition of this variable also closes the gap of previous research which only measures the relationship between situational leadership and learning organizations. Therefore, the results of this study can be more useful and answer the questions and challenges of the disruption era.

There is still relatively little concrete evidence of a positive link between the learning organization into supply chain performance. This can raise question about the benefits of adopting learning organization. It can be questionable, for example, whether a learning organization strategy can contribute to supply chain performance. It is still unclear how strong the contribution will be if it is determined to have a positive contribution, and whether some aspects of the performance will be most affected by theimplementation of learning organization. 
From the perspective of the learning organization, it is important to identify the antecedents of any strategy. The antecedents can provide a useful understanding of the managerial implications of this approach for learning organization seeking a higher level of involvement in supply chain performance. This may help in part to the response to the research, which unambiguously studied the effects of learning organizations on supply chain performance.

Lack of research on the leadership and supply chain driving factors of the company's supply chain performance strategy has limited further theoretical and empirical discussion and the evaluation of performance impact (Ikhwan et al. 2018). leaders promoted the establishment rationally and continued to develop throughout the entire management process of the organization. Leaders can immediately decide to introduce new ideas into the organization, set specific goals, and encourage the learning and innovation of subordinates (Zacher \& Rosing, 2015).

This study aims to examine the relationships that drive learning organizations into supply chain performance, to identify antecedents for learning organizations and those supply chain drivers, and to evaluate the impact of learning organizations on supply chain performance. To this end, first, a conceptual model of relationships was developed through a comprehensive literature review. The model is then expanded through the interpretation of the results from a series of semistructured interviews. The relationships that emerged were then disciplined and tested empirically using structural equation modelling (SEM).

\section{METHODS}

This research took place at the Sekolah Peternakan Rakyat (SPR) Maju Bersama Bojonegoro starting from October to December 2020. Respondents in this study are members of SPR Maju Bersama Bojonegoro. Primary data were obtained by distributing questionnaires to SPR members and in-depth interviews. Secondary data were collected from SPR Maju Bersama performance reports, literature studies and annual reports of the organization.

The questionnaire contains research questions that describe the research variables. The research uses a Likert scale starts from one to five with the following information: Value weight $=5$ (strongly agree): Weight value $=4$ (agree); Value weight $=3$ (neutral); Value weight $=2$ (disagree); Value weight $=1$ (strongly disagree). Data collection using census method. The census was conducted for all 99 members of SPR Maju Bersama.

Data were analysed using the Structural Equation Model - Partial Least Square (SEM-PLS) because it is can be analyzed complex models and predict the model optimally with a little amount of data collected. Descriptive analysis was used to describe the research in general and qualitatively.

The hypotheses of this study were develop by theoretical concepts and previous studies. Schiena et al. (2013) concluded that there is a strong relationship between transformational leadership and learning organizations. Transformational leadership can affect learning organizations (García-morales et al. 2012). In addition, it is important to find that learning organization affected to supply chain performance Khan et al. (2020) and Kohtamaki et al. (2012) found that organization learning stimulate innovation practice on supply chain management which consist two important aspects such as supply chain driver and supply chain performance. Supply chain driver indirectly impacts supply chain performance by impacting retail supply chain efficiency, and supply chain drivers were the most significant determinants of retail supply chain efficiency (Sohel et al. 2016). Based on the theoretical concept and previous studies, the hypothesis of this study are:

H1: Transformational leadership is positively related to the learning organization

$\mathrm{H} 2$ : Learning organization is positively related to supply chain performance

H3 : Learning organization is positively related to supply chain driver

H4 : Supply chain driver is positively related to supply chain performance

The research framework consists of four variables that include transformational leadership, learning organizations, supply chain driver and supply chain performance (Figure 1). Leadership style is a combination of task behaviuor and relationship behaviuor (Jeffrey et al. 2011). Transformational leadership is a leadership style that can increase awareness of collective goals among organizational members and can help all members to achieve 
their common goals (Notgrass, 2014). Leaders achieve results by employing idealized influence, inspirational motivation, intellectual stimulation, and individualized consideration. Learning organization has five subsystems to develop organization. These five subsystems are learning, organization, people, knowledge, and technology (Marquardt, 2002).

According to Chopra \& Meindl (2016), the drivers may affect supply chain performance. This study used supply chain performance indicators that consist of plan, source, make and delivery. Drivers of supply chain performance indicators include facilities, inventory, transportation, information, sourcing, and pricing. These drivers interact with each other to determine supply chain performance in terms of responsiveness and efficiency.

\section{RESULTS}

Evaluation of the measurement model was conducted by reviewing convergent validity. Convergent validity model was assessed by correlation between indicator scores and construct scores (Ghozali, 2016). The loading factor value can be considered reliable if it has a minimum correlation value of 0.5 . Indicators with a loading factor value less than 0.5 are excluded from the model (Figure 2). Indicators whose loading factor values are below 0.5 that include delivery, price, source and transportation were removed from the model. The model was then re-estimated.

The re-estimation results produce all indicators that have met the convergent validity with the loading factor value is above 0.500 (Figure 3). Transformational leadership is reflected by four indicators which are idealized influence, inspirational motivation, intellectual stimulation, and individualized consideration. Learning organization is reflected by five indicators which are learning, organization, people, knowledge, and technology. In contrast, the delivery indicator was removed from supply chain performance, and transportation, source and price indicators were removed from the supply chain driver.

The next step to evaluate the measurement model is discriminant validity. Correlation indicator of Learning Organization (LNG): organization, people, learning, knowledge, and technology with its construct is higher than other constructs (Supply Chain performance (SCP), Supply Chain Driver (SCD) and Transformational (TRF)) (Table 1). Correlation indicator of SCP (make, plan \& source) SCD (facility, information \& inventory); and TRF inspirational motivation, idealized influence, individualized consideration \& intellectual stimulation with its construct is higher than other constructs. Therefore, latent constructs predict indicators in their blocks better than in other blocks.

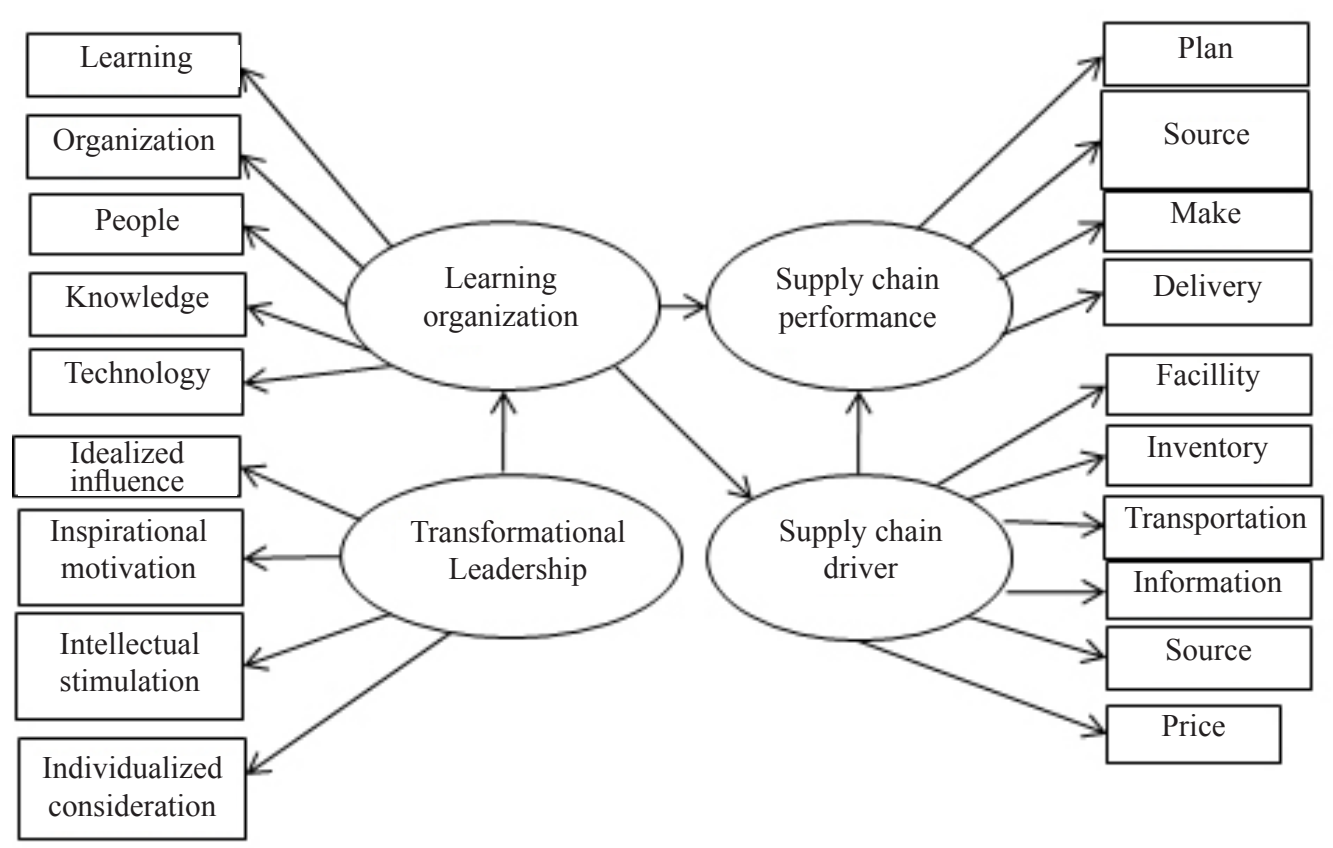

Figure 1: A research framework 


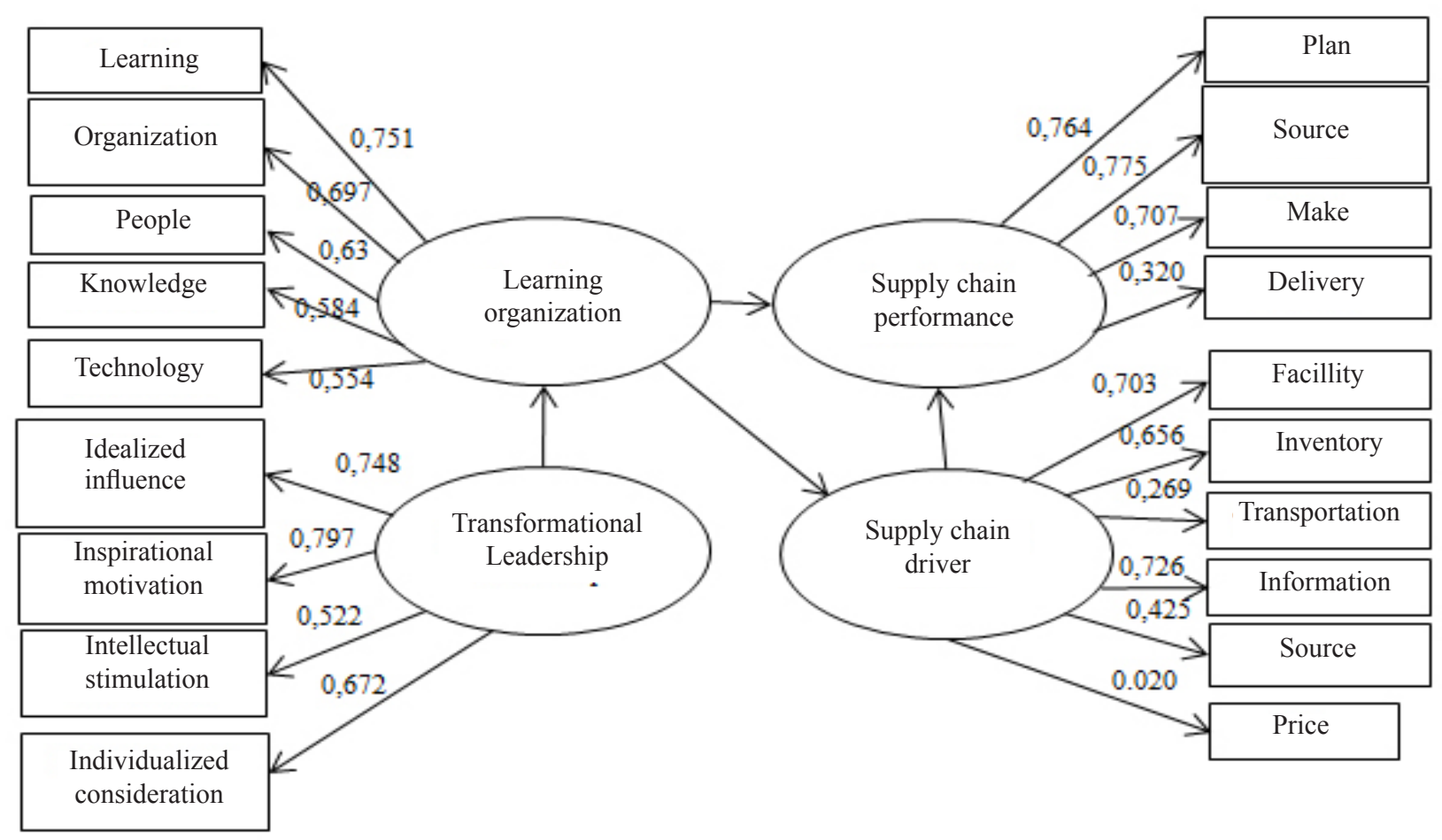

Figure 2. Outer loadings model initial measurement value

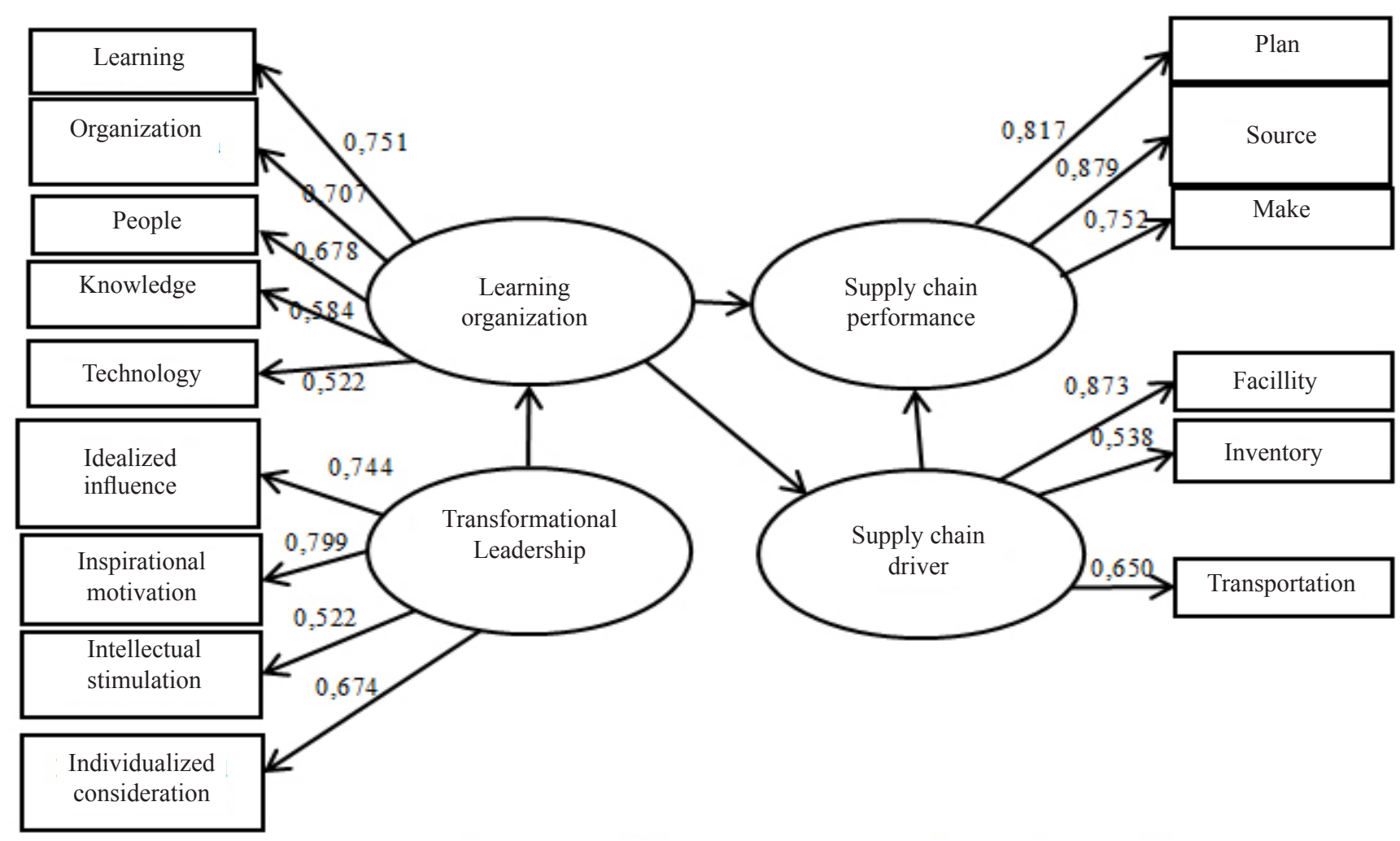

Figure 3. Outer Loadings Model Measurement values after evaluating 
Convergent validity was evaluated by comparing the Average Variance Extracted ( $\mathrm{A}$ AVE) quadratic root for each construct and the correlation between constructs and other constructs. Roots of the AVE of the Learning Organization construct are 0.650 higher than the correlation between the Learning Organization and other constructs (Table 2). Roots of the AVE construct of Supply Chain Performance, Supply Chain Driver and Transformational Leadership also are valid. Therefore, all constructs in the model verify its discriminant validity. Variable Learning Organization, Supply Chain Performance, Supply Chain Driver and Transformational Leadership have good reliability values because the composite reliability value is above 0.700 (Table 3).

Evaluation of structural models was conducted by looking at the R-square value. The R-square value of the Learning Organization construct is 0.243 , which means that the variability of the Transformational Leadership construct can explain the variability of the Learning Organization construct by $24.3 \%$ (Table 4). The Learning Organization construct variability of $75.7 \%$ is explained by other factors outside the model. R-square value of the Supply Chain Performance construct is 0.287 which means that the variability of the Learning Organization and Supply Chain Driver constructs can explain the variability of the Supply Chain Performance construct of $28.7 \%$. Variability of Supply Chain Performance construct of $71.3 \%$ is explained by other factors outside the model. R-Square Supply Chain Driver value is 0.086 which means that the Learning Organization construct variability can explain the Supply Chain Driver variability by $8.6 \%$. The supply chain driver variability of $91.4 \%$ is explained by other factors outside the model.

The results of the path coefficient values showed a positive influence of the Learning Organization on Supply Chain Performance seen from its score of the parameter coefficient of 0.159 (Table 5 There is no significant effect from learning organization to supply chain performance with a t-statistic value of 1.652 (greater than the $t$-table of $5 \%$ significance $=1.96$ ). The learning organization has a positive effect on supply chain driver with a parameter coefficient of 0.293 . Thus, improving learning organization will increase supply chain driver with a significant t-statistic value of 2.418 .
Table 1. Value of cross loadings

\begin{tabular}{lcccc}
\hline & LNG & SCP & SCD & TRF \\
\hline Organisation & $\mathbf{0 . 7 0 7}$ & 0.122 & 0.172 & 0.447 \\
People & $\mathbf{0 . 6 7 7}$ & 0.223 & 0.156 & 0.243 \\
Learning & $\mathbf{0 . 7 5 1}$ & 0.276 & 0.282 & 0.386 \\
Knowledge & $\mathbf{0 . 5 6 4}$ & 0.237 & 0.209 & 0.211 \\
Technology & $\mathbf{0 . 5 2 2}$ & 0.078 & 0.088 & 0.262 \\
Make & 0.303 & $\mathbf{0 . 7 5 1}$ & 0.319 & 0.299 \\
Plan & 0.224 & $\mathbf{0 . 8 1 7}$ & 0.434 & 0.326 \\
Source & 0.216 & $\mathbf{0 . 8 7 9}$ & 0.489 & 0.367 \\
Facility & 0.185 & 0.580 & $\mathbf{0 . 8 7 2}$ & 0.261 \\
Information & 0.319 & 0.171 & $\mathbf{0 . 6 5 0}$ & 0.241 \\
Inventory & 0.170 & 0.140 & $\mathbf{0 . 5 3 7}$ & 0.131 \\
Inspirational & 0.447 & 0.210 & 0.208 & $\mathbf{0 . 7 9 9}$ \\
Motivation & & & & \\
Idealized & 0.396 & 0.450 & 0.233 & $\mathbf{0 . 7 4 4}$ \\
Influence & & & & \\
Individualized & 0.234 & 0.258 & 0.181 & $\mathbf{0 . 6 7 4}$ \\
Consideration & & & & \\
Intellectual & 0.192 & 0.191 & 0.277 & $\mathbf{0 . 5 2 2}$ \\
Stimulation & & & & \\
* bolded numbers & indicate the correlation of the & indicator \\
with its construct & & & &
\end{tabular}

Table 2.Matrix of correlations between latent variables

\begin{tabular}{|c|c|c|c|c|}
\hline & LNG & SCP & SCD & TRF \\
\hline LNG & $\begin{aligned} & \sqrt{ } \mathrm{AVE} \\
= & 0.650\end{aligned}$ & & & \\
\hline SCP & 0.296745 & $\begin{array}{c}\sqrt{ } \text { AVE } \\
=0.829\end{array}$ & & \\
\hline SCD & 0.293729 & 0.514404 & $\begin{array}{c}\sqrt{ } \text { AVE } \\
=0.700\end{array}$ & \\
\hline TRF & 0.493247 & 0.406454 & 0.309673 & $\begin{array}{l}\sqrt{ } \mathrm{AVE} \\
=0.692\end{array}$ \\
\hline
\end{tabular}

Table 3. Construct reliability test

\begin{tabular}{lc}
\hline Constructs & Composite Reliability \\
\hline LNG & 0.782 \\
SCP & 0.857 \\
SCD & 0.735 \\
TRF & 0.782 \\
\hline
\end{tabular}

Table 4. R-Square Values

\begin{tabular}{lc}
\hline Constructs & R Square \\
\hline LNG & 0.243 \\
SCP & 0.287 \\
SCD & 0.086 \\
TRF & \\
\hline
\end{tabular}


Supply chain driver has a positive effect on supply chain performance with a parameter coefficient of 0.467 (Table 5). Therefore, improving supply chain driver will improve supply chain performance with a t-statistically significant value of 7.129Transformational leadership has a positive effect on the learning organization with a parameter coefficient of 0.493. Improving transformational leadership will improve organizational learning with a significant $t$-statistic value of 5,440 .

These results of this study are consistent with the results of Schiena et al. (2013), who showed that transformational leadership has a positive and significant impact on learning organizations. This means that the leader can encourage followers to share and articulate the leader's vision with other followers. Therefore, all followers can express the leader vision. Inspirational motivation becomes the most important aspect for leaders to apply their leadership style. Thus, leaders must motivate their followers to maintain the energy of the effective learning organization.

Organizations need transformational leadership to improve performance in a constantly changing business environments (García-Morales et al. 2012). Transformational leadership can enhance organizational learning and innovation. Furthermore, transformational leadership fully perceived by employees can improve employee performance and organization performance (Cahyono et al. 2015).

Most efforts to improve supply chain performance are based on an economic approach. Improved supply chain performance is based on the trade-off between the use of computing resources and the company's profit and loss. Efforts to improve supply chain performance by strengthening the company's knowledge assets. Therefore, the benefits of this research for practitioners and academics are completely reasonable.
The results show that among the five subsystems of the learning organization, learning and organization are relatively more important because they have higher factor loadings. Organizations should be able to learn to build sustainable organizations (Wen, 2014). Learning is of very importance for the survival and effective performance of the company. Learning is a major component of any effort to improve performance and strengthen competitive advantage. The development of new knowledge reduces the possibility of obsolescence of the company's competencies, keep competencies dynamic and supports performance improvement (García-morales et al. 2012).

As a Learning Organization, there should be no hierarchical structure among the employees of organization. All employees become partners in sincere dialogue. Learning Organization have established a diversified structure and richer capabilities and they truly supports people from the bottom rather than from the authority (Wen, 2014).

The initial objective of the project was to determine the impact of learning organizations on supply chain performance. Surprisingly, the learning organization does not have a significant impact on supply chain performance. This result is contrary to the findings of Sangari et al. (2015), who found that the knowledge management processes has a positive and significant impact on the performance of the supply chain. These results are likely to be related to the organization that did not make decisions for knowledge-based supply chain decisions.

Knowledge-based chain decision-making is needed to encourage effective action. Knowledge is important to identify weaknesses and areas that need improvement, and then develop appropriate practices to correct them. Focussing on this knowledge are relatively more effective in improving performance (Sangari et al. 2015).

Table 5. Path Coefficients (Mean, STDEV, T-Values)

\begin{tabular}{lccccc}
\hline & $\begin{array}{c}\text { Original Sample } \\
(\mathrm{O})\end{array}$ & $\begin{array}{c}\text { Sample Mean } \\
(\mathrm{M})\end{array}$ & $\begin{array}{c}\text { Standard Deviation } \\
(\text { STDEV })\end{array}$ & $\begin{array}{c}\text { Standard Error } \\
(\text { STERR })\end{array}$ & $\begin{array}{c}\text { T Statistics } \\
(|\mathrm{O} / \mathrm{STERR}|)\end{array}$ \\
\hline $\mathrm{LNG} \rightarrow \mathrm{SCP}$ & 0.159 & 0.137 & 0.096 & 0.096 & 1.652 \\
$\mathrm{LNG} \rightarrow \mathrm{SCD}$ & 0.293 & 0.367 & 0.121 & 0.121 & 2.418 \\
$\mathrm{SCD} \rightarrow \mathrm{SCP}$ & 0.467 & 0.474 & 0.065 & 0.065 & 7.129 \\
$\mathrm{TRF} \rightarrow \mathrm{LNG}$ & 0.493 & 0.530 & 0.090 & 0.090 & 5.440 \\
\hline
\end{tabular}


In this study, it was found that learning organization can lead to supply chain driver. This finding is consistent with the findings of Ikhwan et al. (2018), who also mentioned that the better implementation of the learning organization, the more optimal the supply chain driver is. These results further support the concept of knowledge, which can enhance adaptability in higherlevels learning, and the development of products, services, and technologies (Ramanathan et al. 2011). This is a useful output for the organization to improve information, facilities, and resources. Knowledge can transform the perspectives of members from resourcebased management to technology-based management. They realize that information technology is the source of competitiveness.

Every organization must analyze its information technology resources, which can achieve for a better competitive position. Organizations must develop specific competencies to respond changes in production and technology in their environment (García-morales et al. 2012). The quality of the information adds more value to the forecasting process, so it must be measured regularly. Improving forecast accuracy will be an effective indicator of information exchange. If technology is used to exchange information, its efficiency can be measured by the accessibility of members of the supply chain to the information. Based on this, any business can make decisions about investment in technology (Ramanathan et al. 2011).

Another important finding is that the supply chain driver have a significant positive impact on supply chain performance, which is consistent with Ikhwan et al. (2018). Control facilities is important in strategic planning by reducing facility costs (Shahzadi et al. 2013). Organization should optimize facilities to make them more efficient. Shahzadi et al. (2013) said that the efficiency of small is lower than that of large one. Rana and Goel (2014) mentioned that information improves efficiency by speeding up work and decision-making. Nath and Standing (2010) believes that information can improve the capabilities of supply chain member. Supply chain members can share their knowledge, resources, and skills, create networks, learning, and innovate, and improve their ability to innovate.

\section{Managerial Implications}

This study suggests that organizational leader should encourage the followers to share and articulate the leader's vision. The second key to improve the application of learning organization is how leaders motivate followers. Inspiring followers can increase their willingness to make positive changes in the learning process. The third key to increasing the application of learning organizations is to stimulate the intelligence of subordinates by increasing creativity and innovation. The last key is to pay attention to how to train subordinates listen to their aspirations and guide them.

The results of this study do not indicate that learning organizations have an impact on supply chain performance. The learning organization only has an impact on supply chain drivers. These findings suggest that organizations should develop a system of learning organization systems to make better use of supply chain drivers. Development of learning can provide a wide range of knowledge for decision-making. The knowledge possessed by the members of the organization enables them to make better decisions in selecting facilities more effectively, managing supplies efficiently, and being able to use the information they have to increase profits. The results of this study also show that an important aspect that can improve supply chain performance is through the development of supply chain drivers. The organization's use of the information to plan, manage resources, and manage production well.

\section{CONCLUSIONS AND RECOMMENDATIONS}

\section{Conclusions}

The present study aims to determine the impact of learning organization on supply chain performance. The results of this study show that learning organizations do not have significant impact on supply chain performance The evidence from this study shows that the organizations that develop learning organizations cannot improve their supply chain performance. Transformational leadership has become as reliable predictors of learning organization. This finding shows that the higher transformational leadership practiced by organizations will increase the learning organizations. The learning organization has a significant positive impact on supply chain drivers. This finding show that the higher learning organization practiced by the organization will have a more positive impact on supply chain drivers. This study also found that supply chain driver is significantly impact on supply 
chain performance. This finding shows that the higher the supply chain driver practiced by organization will increase supply chain performance.

\section{Recommendations}

Further research on the role of innovation and the impact of the knowledge management processes will be worthwhile. However, innovation and knowledge management processes play an important role in context that stimulate employee performance and learning capability. Heterogeneous samples that will be collected from the various industries may provide broader information on the relationship between leadership, learning organizations, supply chain drivers and supply chain performance. Future research may study many small and medium-size industries, such as manufacturing, services, or textiles.

\section{REFERENCES}

Akhmadi,SiregarH,Hutagaol MP.2016.Pengembangan agribisnis sebagai strategi penanggulangan kemiskinan di perdesaan. Jurnal Manajemen Dan Agribisnis 13(3):240-253. https://doi. org/10.17358/jma.13.3.240.

Allameh SM, Zare SM. 2011. Procedia computer science examining the impact of KM Enablers on knowledge management processes. Procedia Computer Science 3(1):1211-1223. https://doi. org/10.1016/j.procs.2010.12.196.

Aragón MIB, Jiménez DJ, Valle RS. 2014. Training and performance: The mediating role of organizational learning. Business Research Quarterly:1-13.

Baba Y. 2015. Does learning orientation matter for nonprofit organization performance? Empirical evidence from Ghana.Leadership \& Organization Development Journal 36(1):234-252. https:// doi.org/10.1108/LODJ-05-2013-0056.

Cahyono UT, Maarif MS, Suharjono. 2015. Pengaruh kepemimpinan transformasional terhadap kinerja karyawan di perusahaan daerah perkebunan Jember. Jurnal Manajemen \& Agribisnis 11(2):68-76.

Chopra S, Meindl P. 2016. Supply Chain Management: Strategy, Planning, and Operation. Ed. ke-6. London: Pearson.

García-morales VJ, Jiménez-barrionuevo MM, Gutiérrez-gutiérrez L. 2012. Transformational leadership in fluence on organizational performance through organizational learning and innovation. Journal of Business Research 65(7):1040-1050. https://doi.org/10.1016/j. jbusres.2011.03.005.

Ghozali I. 2016. Aplikasi Analisis Multivariate dengan Program IBM SPSS 23. Ed. ke-8. Semarang: Badan Penerbit Universitas Diponegoro.

Grint K. 2014. A History of Leadership: In The SAGE Handbook of Leadership. New York: Sage.

Hung R, Yuan Y, Yang B, Lien BY, Mclean GN, Kuo Y. 2010. Dynamic capability: Impact of process alignment and organizational learning culture on performance. Journal of World Business 45(3):285-294.https://doi.org/10.1016/j. jwb.2009.09.003.

Hussein N, Mohamad A, Noordin F, Ishak NA. 2014. Learning organization and its effect on organizational performance and organizational innovativeness: A proposed framework for malaysian public institutions of higher education. Procedia - Social and Behavioral Sciences 130:299-304. https://doi.org/10.1016/j. sbspro.2014.04.035.

Ikhwan K, Sukmawati A, Cahyadi ER. 2018. The implementation of learning organization in order to increase supply chain performance in SPR Maju Bersama Bojonegoro. Jurnal Manajemen Dan Agribisnis 15(1):83-95. https://doi. org/10.17358/jma.15.1.83.

Jeffrey I, Hermawan A, Hubeis M, Djohar S. 2011. Pengaruh kecocokan gaya kepemimpinan dan budaya organisasi terhadap kinerja individu: Studi kasus PT. XYZ. Jurnal Manajemen \& Agribisnis 8:97-107.

Khan A, Tao M, Ahmad H, Shafique MN, Nawaz MZ. 2020. Revisiting green supply chain management practices: The mediating role of emotional intelligence. SAGE Open 10(1):1-13. https://doi. org/10.1177/2158244020914637.

Kim K, Watkins KE, Lu Z. 2017. The impact of a learning organization on performance: focusing on knowledge performance and financial performance. European Journal of Training and Development 41(2):1-31. https://doi. org/10.1108/EJTD-01-2016-0003.

Kohtamaki M, Kraus S, Makela M, Ronkko M. 2012. The role of personnel commitment to strategy implementation and organisational learning within the relationship between strategic planning and company performance. 
International Journal of Entrepreneurial Behaviour \& Research 18(2):159-178. https:// doi.org/10.1108/13552551211204201.

Marquardt JM. 2002. Building the Learning Organization: Mastering the 5 Elements for Corporate Learning. Ed. ke-2. Palo-Alto: Davies-Black Publishing.

McCleskey J. 2014. Situational, transformational, and transactional leadership and leadership development. Journal of Business Studies Quarterly 5(4):117.

Nath T, Standing C. 2010. Drivers of information technology use in the supply chain. Journal of SystemsandInformation Technology 12(1):70-84. https://doi.org/10.1108/13287261011032661.

Nold HA. 2011. Making knowledge management work: Tactical to practical. Knowledge Management Research and Practice 9(1):84-94. https://doi. org $/ 10.1057 / \mathrm{kmrp} .2010 .27$.

Notgrass D. 2014. The relationship between followers ' perceived quality of relationship and preferred leadership style. Leadership \& Organization Development Journal 35(7):605-621. https:// doi.org/10.1108/LODJ-08-2012-0096.

Ramanathan U, Gunasekaran A, Subramanian N. 2011. Supply chain collaboration performance metrics: A conceptual framework. Benchmarking 18(6): 56-872. https://doi. org/10.1108/14635771111180734.

Rana G, Goel A. 2014. Ethan learns to be a learning organization: Culture change prompts greater openness and empowerment. Human Resource Management International Digest 22(6):12-14. https://doi.org/10.1108/HRMID-08-2014-0114.

Sangari MS, Hosnavi R, Zahedi MR. 2015. The impact of knowledge management processes on supply chain performance: An empirical study. The International Journal of Logistics Management 26(3): 603-626. https://doi.org/10.1108/IJLM09-2012-0100.

Santos-Vijande ML, López-Sánchez JÁ, Trespalacios JA. 2012. How organizational learning affects a firm's flexibility, competitive strategy, and performance. Journal of Business Research 65(8):1079-1089. https://doi.org/10.1016/j. jbusres.2011.09.002.

Schiena RD, Letens G, Aken E, Van, Farris J. 2013. Relationship between leadership and characteristics of learning organizations in deployed military units: An exploratory study. Administrative Sciences 3:143-165. https://doi. org/10.3390/admsci3030143.

Sohel, Rana SM, Osman A, Manaf AH, Ab Halim MS, Solaiman M. 2016. Drivers of retail supply chain efficiency: Moderating effect of lean strategy. International Journal of Supply Chain Management 5(1):52-62.

Styhre A, Josephson PE, Knauseder I. 2010. Learning capabilities in organizational networks: case studies of six construction projects. Construction Management and Economics 22(9):957-966. https://doi.org/10.1080/0144619042000241417.

Wen H. 2014. The nature, characteristics and ten strategies of learning organization. International Journal of Educational Management 28(3):289298. https://doi.org/10.1108/IJEM-04-20130062.

Zacher H, Rosing K. 2015. Ambidextrous leadership and team innovation. Leadership \& Organization Development Journal 36(1):54-68. https://doi. org/10.1108/LODJ-11-2012-0141. 